\title{
L'Amant Double Filminde Öteki Mekân Temsili Olarak Heterotopya
}

\author{
Muhsine Sekmen*
}

Özet

Modern yaşama geçiş ile birlikte iktidar ve özne ilişkisinin biyo-iktidar ile şekillendiğini düşünen Michel Foucault, bireyi sinırlandiran bu yapidan kurtulmanin bir yolu olarak heterotopya kuramin geliştirmiştir. Biyo-iktidar içten gelen bir buyruk olarak iktidarın istediği normal insanı tanımlamaktadır. Modern kent hayatı, bireye iş yaşamı içerisinde iktidara uygun bir yaşam biçimi sunarken, bu kurallara aykırn davranan bireyler ise toplumdan uzaklaşmak isteyerek kendilerine yeni mekânlar oluşturmaya çalışmaktadır. Bu kapsamda Foucault yirminci yüzyılda bireylerin yaşadıkları kaygının temelinde mekân fikri olduğunu savunurken yeni mekânlar oluşturma fikrini yani heterotopyayı öne çıkarmak istemektedir.

Bu çalışma Foucault'nun heterotopya ve Stavrides'in eşik kuramını temel alarak François Ozon'un L'Amant Double filminde öteki mekan temsili olarak heterotopya alanlarm incelemektedir. L'Amant Double filminde dikkat çekici bir şekilde kullanılan heterotopya alanları çalışmanın örneklemi olarak seçilmesinde etkili olmuştur. Bu kapsamda sapma heterotopyalar olarak psikiyatri klinikleri, zaman heterotopyaları olarak müzeler, olmayan yer olarak ayna heterotopyası ve eşik mekânları olarak köprüler ve merdivenler filmde incelemeye alınan kategorilerdir. Bu çalışma, L'Amant Double filminde öteki mekân temsili olarak heterotopya alanlarna bakarken, heterotopyanın sinemada evrilen biçimlerini göstermeyi amaçlamaktadır.

Anahtar kelimeler: Heterotopya, Foucault, Sinema

ORCID ID : https://orcid.org/ 0000-0001-5493-9927

E-mail : muhsine.sekmen@atauni.edu.tr

DOI: $10.31122 /$ sinefilozofi.703451

Geliş Tarihi - Recieved: 13.03.2020

Kabul Tarihi - Accepted: 10.11.2020 


\title{
Heterotopia as a Represresentation of Other Space in the movie L'Amant
}

\author{
Muhsine Sekmen*
}

\begin{abstract}
Considering that the relationship between power and subject is shaped by biopower with the transition to modern life, Michel Foucault developed the theory of heterotopia as a way to get rid of this structure that limits the individual. While modern urban life offers the individual a life style which is in accordance with power in the business life, individuals who go against these rules try to create new spaces for themselves by wanting to alienatine from society. In this context, while Foucault argues that there is the idea of space in the basis of the anxiety of individuals in the twentieth century, he wants to highlight the idea of creating new spaces, namely heterotopia.

Based on Foucault's heterotopia and Stavrides' thresholds theory, this study examines the areas of heterotopia as a represantation of the other space in François Ozon's L'Amant Double. The heterotopia areas that were used remarkably in the movie L'Amant Double were effective in selecting the study as a sample. In this context, psychiatry clinics as deviation heterotopias, museums as time heterotopias, mirror heterotopia as a non-existent place and bridges and stairs as threshold areas are the categories that are examined in the film. This study aims to analyse the forms of heterotopia which has been presented in different ways in cinema while studying the fields of heterotopia as the representation of the other space in L'Amant Double.
\end{abstract}

Key Words: Heterotopia, Foucault, Cinema

ORCID ID : https:/ /orcid.org/ 0000-0001-5493-9927

E-mail :muhsine.sekmen@atauni.edu.tr

DOI: $10.31122 /$ sinefilozofi.703451

Geliş Tarihi - Recieved: 13.03.2020

Kabul Tarihi - Accepted: 10.11.2020 


\section{Giriş}

Sanayileşmeyle birlikte başlayan kentleşme olgusu insanların metropol şehirlerde yoğunlaşmasına neden olmuştur. Farklı kimliklerin bir araya gelmesiyle oluşan metropol hayatı, birlikte yaşamanın gerekliliği olarak, iktidar denetimi ile kontrol altına alınmaktadır. Bu kapsamda iktidar, kentsel yapıda kapitalist üretimi sağlama almak için mekânsal düzenlemelere giderek mekânları sınıflandırmaya ve hiyerarşiler halinde düzenlemeye çalışmaktadır (Stavrides, 2018: 28). Mekânlar üzerinden insanı sınırlandıran ve sınıflandıran bu anlayış, sosyolojik yapısalcı bakış açısının tezahürü olarak, insan ve mekân anlayışına üst akılcı bir anlam katmaktadır. Yapısal işlevselci kurama göre, toplum bir sistemdir ve bu sistem kendi içinde alt sistemlere ayrılmaktadır. Bu yapı içerisinde her bir alt sistem belirli işlevleri yerine getiren kapsamlı bir eylem sistemidir (Richter, 2013: 116). Bu sistem, toplum içinde yer alan her bir kurumun toplumsal yapıya hizmet etmesi gerekliliğinden hareket etmektedir. Bu kapsamda toplumsal yapı içerisinde yer alan aile, din, eğitim sistemi ve hapishaneler -ki bu kurumların hepsi bir mekân tasavvuruna denk düşmektedir- yapıyı güçlendirmeye ve yapının devamlılığını sağlamaya çalışmaktadır.

Mekân, toplumun içinde yer aldığı basit bir kap değil, toplumsal eylemlerin gerçekleştiği bir zemindir (Stavrides, 2016:11). Bireyin eylemlerini, düşüncelerini ve düşlerini şekillendiren güçlü bir özelliğe sahiptir. Henri Lefebvre' ye göre mekân;

“... şeyler arasında bir şey, ürünler arasında herhangi bir ürün değildir, onlarm ortak varliklarn ve eşzamanlılıkları içindeki ilişkilerini yani düzeni veya düzensizliği kapsar. ......mekan, geçmiş eylemlerin sonucu olarak yeni eylemlere imkan tanır, bunlar telkin eder ya da engeller." (2014: 99).

Buna göre mekân kavramının içinde düzen ve düzensizlik olduğu kadar eylemlerin neden sonuç ilişkisiyle bağlandığı bir yapıdan bahsedilmektedir. Jeremy Bentham'ın geliştirdiği panoptikonu iktidar ve mekân ilişkisi bağlamında çalışmalarında yer veren Foucault, panoptikonun görülmeden gözetlemeye imkân veren bir sistem olarak işlerliğinden bahsetmektedir. Panoptikonda insanların kapatılarak ışık alan hücrelere yerleştirilmesi, görünürlüklerini artırarak saklanmalarını imkânsız hale getirmektedir. Bu anlamda Foucault, panoptikonu insanları kontrol altında tutmanın, eğitmenin ve istenmeyen davranışlardan alıkoymanın sağlanabileceği ayrıcalıklı bir yer olarak değerlendirmektedir (2017: 296-301).

Foucault, iktidar ve insan arasındaki ilişkileri düzenleyen sistemi biyo-iktidar kavramı ile açıklamaktadır. Biyo-iktidar ${ }^{1}$, insana özne olma koşulu sağlamasının garantörü olarak işlemekte ve bu nedenle toplumsal yapının ve iktidarın istediği özne olma davranışlarının içten gelen bir buyruk olarak görülmesini ifade etmektedir.

Diğer taraftan iktidar, kapitalist toplum yapısında normalleştirme mekanizmalarını işletmeye çalışmaktadır. Buna göre;

- Normalleştirme, toplumsal öznenin belirli davranış biçimlerini sınıflandırır ve bunlarla uyumlu mekân kullanımını düzenler.

- Normalleştirme, dıştan gelen bir baskı mekanizması değil, içten gelen (biyoiktidar) bir buyruk olarak toplumun kılcal damarlarına nüfuz etmesi gerekir (Stavrides, 2018: 2018).

- Normalleştirme, özneyi toplumsal yapının işlerliğinde merkezi bir konumda

\footnotetext{
${ }^{1}$ Foucault on yedinci yüzyılın sonundan itibaren Batı toplumlarında yeni bir iktidar biçiminin egemen olduğunu ifade eder. Foucault bu iktidarı biyo-iktidar olarak adlandırır. Foucault'ya göre biyo-iktidar yaşama iki biçimde müdahale eder. İlkinde İnsan bedenini bir makine olarak gören disiplinci iktidar, bedenin terbiye edilmesi, yeteneklerinin artırılması, güçlerinin ortaya çıkarılması, .....ve ekonomik denetim sistemleriyle bütünleştirilmesini ister. İkincisi, nüfusun biyo-politiğidir. Bedenin biyolojik süreçlerinin temelinde üreme, doğum ve ölüm oranları, sağlık düzeyi, yaşam süresi gibi bir dizi denetim ve müdahaleyi içerir.

Biyo-iktidar, kapitalizm için vazgeçilmez bir konumda yer almaktadır. Kapitalizm bedenlerin üretim süreci içerisinde çalıştırılması, ekonomik süreçlere uygun olarak nüfusun düzenlenmesini güvence altına almak istemektedir (Foucault, 2015: 99-100).
} 
tutarken, aynı zamanda sıradanlaştırmaktadır.

Tüm bu normalleştirme mekanizmaları, bireyin toplumsal kurallara uyarak ve mekânlara uygun davranış pratikleri geliştirerek nihayetinde toplumsal özne olarak yapının işlemesine hizmet etmektedir. Ancak bu toplumsal yapıya uymayan ve sapkın davranış gösterenler ise iktidar tarafından belirlenmektedir. "Hapishanenin Doğuşu" adlı eserinde Foucault, mekân ve beden ilişkisinin disiplin ve sapma unsurları bağlamında değerlendirmektedir. Foucault, orduda, okulda ve çalışma alanlarında zaman kullanımı, iş ahlakı, tavır ve davranışlar, beden ve cinselliğin uygun olmayan biçimde kullanılması ve sergilenmesinin cezalandırma sistemine tabi olduğunu ifade eder (2017:266). Özellikle cinsellik de bundan nasibini alarak iktidar tarafından gereksiz enerjilerin ve hazların bastırılması şeklinde uygulamaya yansımıştır (2015:16). Böylece iktidar, kuralları ve buna uyulmaması durumunda cezaları belirterek insanın sapma davranışında bulunmasının önüne geçmeye çalışmaktadır. Bu anlamda iktidar, normal olanı inşa ederken, sapkın olanı ise işaretleyerek damgalamaktadır (Stavrides, 2018: 32). İktidarın mekânı düzenleme ve inşa etmesi örnekleri olarak düşünebileceğimiz, havaalanları, alışveriş merkezleri ve bankalar güvenlik kontrol mekanizması oluşturarak, normal davranıştan sapanları belirleme mecraları olarak dikkat çeker. Alışveriş merkezlerinde havaalanlarında insanlar sapkın davranışa sahip olmadıklarını yani terörist olmadıklarına dair, kontrollerden geçmek zorundadır (Stavrides, 2018: 32-34).

\section{Michel Foucault'nun Heterotopya Kuramı}

Bu noktaya kadar genel çerçeveye bakıldığında insan ve mekân ilişkisinin rastgele bir ilişki biçimi olmadığı, iktidarın belirlediği pratikler ekseninde gelişen bir alan olduğu dikkat çekmektedir. Belki de bu nedenden dolayı, Foucault yirminci yüzyılı mekân dönemi olarak kabul etmekte ve insanların yaşadıkları kaygının temelinde mekân olduğunu düşünmektedir (2011: 291-293) Buna göre, insanlara belirli kimlikleri dayatan mekânlarla insanlara çok yönlü ve açık kimlikler sunan mekânları birbirinde ayırt etmek gerekmektedir (Stavrides, 2018: 227). Yani, çok yönlü kimlikleri bir geçiş mekânı olarak değerlendirilebilecek heterotopyalar olduğunu söylemek mümkündür. Foucault, mekâna ilişkin çalışmalarında ütopya ve heterotopya kavramlarına başvurmaktadır. Ona göre ütopyalar;

"Gerçek yeri olmayan mevkilerdir. Bunlar toplumun gerçek mekânıyla doğrudan ve tersine dönmüş, genel bir analoji ilişkisi sürdüren mevkilerdir. Bu ya mükemmelleşmiş toplumdur ya da toplumun tersidir; fakat her halükarda bu ütopyalar özünde esas olarak gerçekdışı olan mekânlardır" (2011: 295).

Ütopyaları özünde gerçek olmayan mekânlar olarak tanımlamasına karşın, heterotopyaların gerçek olma niteliğine vurgu yapmaktadır. Gerçek olma niteliğine sahip heterotopyalar, ikili bir mekân tasavvuru sunmaktadır. Buna göre ya bireyin toplumsal yapıdan kaçarak oluşturduğu heterotopya mükemmel bir mekân anlayışıdır ya da toplum tarafından normalin dişında kabul edilen öteki mekânlardır. Bireyi içinde bulunduğu toplumdan kurtulma isteği yaratan heterotopyanın modern toplum yapısılla bağlantılı olduğu görülmektedir. Foucault'ya göre aydınlanma, aklın siyasi güçlerini çoğaltmayı bir görev haline getirmişti. Böylelikle rasyonelleşme eğilimindeki bir toplum, birey özgürlüklerine, canlı türlerine ve onların hayatta kalmalarına yönelik tehditler içermeye başlamıştır (2011: 26). Foucault'nun çalışmalarında yer alan deliler ve suçlular, aydınlanmanın ve rasyonelitenin dışarıda bıraktığı alanda yer almaktadır. Zaten Foucault, delileri psikiyatriye yönlendirerek, suçluları ceza sistemine tabi tutarak; yani ötekileri dışlayarak kendimizi dolaylı yoldan kurduğumuzu ifade etmektedir (2011: 107). Foucault, modern toplumda kapatılanların sadece deliler değil, tembeller, işsizler, aile kurallarına uymayanlar ve normal dışı olan insanlar olduğunu söyler (Akt. Canpolat, 2005: 116-119). Böylece bu normal olmayan insanlar kapatılarak aslında toplumdan tecrit edilmişlerdir. Daha sonraları iş gücü eksiği oluşması nedeniyle deliler dışındaki insanlar çalışma hayatının içerisine dâhil edilerek, psikolojik problemi olan hasta insanlar olarak kabul edildiler (Canpolat, 2005:120-121). Böylece modern sistem kendi içinde aklı ve çalışmayı ön plana alan yapısı itibariyle farklı niteliklere sahip insanları içinde barındırmaktadır. Birey ise, yapının onlara dayatmış olduğu duvarı yıkmaya çalışarak yeni mekân arayışlarına 
yönelmektedir. Bireyin yeni mekan arayışına yönelmesi, Foucault'nun özne ve iktidar arasında kurulan disiplinci söylem ile ilişkisi bulunmaktadır. Butler Foucault' daki disiplinci söylemi şu sözlerle açıklamaktadır:

"Foucault'daki disiplinci söylem, tek tarafl olarak özneyi yapılandırmaz, öyle yapsa bile eşzamanlı olarak öznenin yapı-sız-lanması koşulların üretir. ... Foucault'ya göre disiplinci aygıt, özneleri üretir, ama bu üretim sonucunda bu aygıtın kendisini tahrip etme koşullarını söyleme getirir" (2015: 100-101).

Disipline eden aygit bir taraftan özneyi inşa ederken diğer taraftan öznenin istenmeyen davranışlarını da oluşturmaktadır. Hetereotopya ise öznenin inşa koşullarında istenmeyen davranışlara sahip olanların dışlandıkları ya da kaçmak istedikleri alanlar olarak dikkat çekmektedir. Demek ki, burada bireyi mekân aramaya yönelten temel etki, bireyin içinde bulunduğu durumdan kurtulma isteğidir. Toplum içinde kırılgan, hassas, bölünmüş ve parçalanmış benlikler, kendilerini diğer insanlardan tecrit etme yoluna gitmektedirler (Yılmaz, 2018:41). Birey, toplumsal -yaşamda benliğinin yara alması ile kendisine heterotopya oluşturmaya çalışmaktadır.

Foucault'nun heterotopya kuramı uzamsal bir ötekilik sunmaktadır. Aslında heterotopya ötekiliğe, çoğulculuğa ve heterojenliğe kapı aralayarak, baskıdan kaçış alanı yaratmaktadır (Sudradjat, 2012:32). Bu anlamda tecrit etme, bir taraftan iktidarın bireyi dişlaması yoluyla gerçekleşirken, diğer taraftan bireyin kendisinin toplumsal koşulların dayatmasından kurtulması için yeni bir mekâna yönelmesi yoluyla da gerçekleşebilmektedir. Böylece kentleşme ve modern yaşamın bireyin psikolojik çıkmaza girmesine zemin hazırladığı söylenebilir (Yilmaz, 2018:43). Foucault, beden ve mekân ilişkisini incelerken, bedeni toplumsallaşma, baskı altına alma, disipline etme ve cezalandırmanın merkezinde görmektedir. Mekân içinde var olan beden, ya otoriteye boyun eğmeli, ya da kendisi için direniş ve özgürlük alanları yaratmalıdır (Harvey, 2010:239). Direniş ve özgürlük alanları olarak bahsedilen ise heterotopyalardir.

Foucault heterotopyaları altı biçimde sınıflandırmaktadır. Foucault ilk heterotopyanın ilkel toplumlarda vücut bulmuş hali olan kriz heterotopyaları olduğunu ileri sürer. İlkel toplumlarda adetli kadına, hamile kadına, yeni doğmuş çocuğa ve yaşlılara ayrılmış alanlar kutsal ya da yasak olan alanlar bulunmaktadır. Kriz heterotopyalarının günümüz toplumlarında da var olduğundan yola çıkan Foucault, genç erkeklerin cinselliğini kanıtlamasının ve genç kızların bekâretini kaybetmesinin mekân ile olan ilişkisinden bahseder. Buna göre, genç bir erkek için yatılı okullar ve askerlik yaptığı mekânlar evden uzakta cinselliğin kanıtlandığı mekânlar olarak dikkat çekmektedir. Genç kız için ise evlendiği zaman balayı odaları onun bekâretinin yitirildiği hiçbir yer olarak değerlendirilen heterotopik alanlardır (Foucault 2011:296-297). Foucault kriz heterotopyalarının günümüz toplumlarında yerini sapma heterotopyalarına bıraktığını düşünmektedir. Sapma heterotopyaları kriz heterotopyalarının yeni bir görünümü olarak tezahür etmektedir. İktidar toplumda normalleşmeyi sağlamak adına mekân ve davranış biçimlerini kategorize ederken buna uymayan davranış biçimlerini ise sapkın olarak nitelendirmektedir. Sapma heterotopyaları Foucault' nun "Hapishanenin Doğuşu" ve "Deliliğin Tarihi" eserlerinde yer alan toplumdan dışlanan ve ötekileştirilen davranışları gösterenler olarak tanımlanabilir. Sapma heterotopyaları, davranışları normalleştirilemeyenlerin yerleştirildikleri mekânlardır. Psikiyatri klinikleri, hapishaneler, tımarhaneler, huzurevleri (yaşlılık hem kriz hem de sapma davranış olarak kabul edilmektedir.) sapma davranışı gösterenlerin yerleştirildikleri heterotopik mekânlardır (Foucault, 2011:297).

Foucault ikinci tip heterotopyaları mekânın zamanla değişen algısı ile ilişkili olarak görmektedir. Bu kapsamda Foucault mezarlık heterotopyasını inceler ve onun öteki mekan olarak görülmesinin izini sürer. Mezarlık, diğer kültürel mekânlarla kıyaslandığı zaman başka bir yer olarak görülmektedir. Ancak içinde yer aldığı şehrin insanlarının bu mezarlıkta akraba ve tanıdıkları olması nedeniyle bağları bulunmaktadır. Foucault'ya göre Batı toplumunda 18. Yüzyıldan sonra mezarlıkların şehrin dışına taşınmasında ölüm ve hastalık arasındaki ilişki neden olmuştur. İnsanların ölülerin ve dolayısıyla mezarlıkların hastalık getirdiğine ilişkin inanca sahip olması evlerin yanı başındaki mezarlıkların şehrin dışına taşınmasına neden 
olmuştur. Böylece, mezarlıklar kutsal vasfından uzaklaştırılarak hastalık getiren öteki şehir olarak nitelendirilmesine neden olmuştur (Foucault, 2011:298).

Üçüncü tip heterotopyalar, birçok farklı unsuru içinde bulunduran mekânlar olan heterotopyalardır. Tiyatro, sinema, bahçe (Acem bahçesi), bahçenin yeniden taklidi olarak görülebilecek halı bu heterotopya içinde yer alır. Tiyatro ve sinema heterotopyası, farklı mekânsal unsurları içinde bulundurarak izleyicisine sunmaktadır. Sinema heterotopyası, üç boyut bir evreniçindeiki boyutlu heterotopyalar oluşturmaktadır (https:/ / thefunambulist.net/ cinema/heterotopias-in-cinema-introduction).Gelişen teknoloji de sinema heterotopyası içine üç boyutlu heterotopik alanlar inşa etmektedir. Bu anlamda sinema heterotopyası dediğimizde hem sinema evreninin kendisi bir heterotopya olmakta hem de sinema filmlerinde izleyiciye sunulan heterotopik alanlar ile iki kez heterotopya haline gelmektedir. Bahçe ise, farklı kültürlere ait bitkilerin yer aldığı dünyanın dört bir köşesini bir araya getiren kutsal bir mekân olarak kabul edilmektedir (Foucault, 2011:298). Kapitalizmle birlikte değişen mekân algısının insanı doğadan koparması ve insanı soyut mekânlara kapatması, bahçe heterotopyasının bir nedeni olarak görülmelidir. Çünkü insan kapitalizmin işlerliğini sağlayacak yapay mekânlara yönlendirilirken, doğa toplumsal yaşamdan uzaklaştırılmaktadır (akt Urry, 2015:48).

Dördüncü tip heterotopyalar farklı zaman unsurlarını bir arada bulunduran zaman heterotopyalarıdır. Müzeler ve kütüphanelerin içerisinde yer aldığı bu heterotopyalar, on dokuzuncu yüzyıl batı kültürüne ait olarak değerlendirilmektedir.

Foucault zaman heterotopyalarını şu şekilde tanımlamaktadır:

"Her şeyi biriktirme fikri, bir tür genel arşiv oluşturma fikri, bütün zamanlarn, bütün dönemleri bütün biçimleri bütün zevkleri bir yere kapama istenci, zamanın dışında yer alacak ve zamanın zarar vermeyeceği bir yer oluşturma fikri, kımıldamayacak bir yerde zamanın bir tür kalıı ve sonsuz birikimini örgütleme projesi..." (Foucault, 2011:299).

Kısaca zaman heterotopyalarını farklı zamanlarda varlık gösteren eserlerin bir araya getirildiği zamansal birikim mekânları olarak değerlendirebiliriz. Beşinci heterotopya türü, açılma ve kapanma sistemine sahip olan heterotopyalardır. Foucault bu tür heterotopyalara girişlerin keyfi olmadığından bahseder. Bu heterotopyalara hapishane ve kışla örneğinde olduğu gibi ya zorla ya da belirli davranışları yerine getirmek koşuluyla girilmektedir (Foucault, 2011:300).

Bir başka heterotopya, herkesin girmesine izin verildiği ancak bir yanılsama olarak içeriye tam olarak girilmeyen heterotopyalardır. Bu heterotopyalar, bir eve girildiği izlenimi yaratmış olsa da ailenin olduğu odaya girilmesine izin verilmeyen yanılsama yaratan heterotopyalardır. Foucault bu heterotopyaların Güney Amerika'nın büyük çiftliklerinde var olan ünlü odalarda bir zamanlar var olduğunu düşünmektedir. Günümüzde ise bu heterotopyanın Amerikan motellerinde metresle gidilen ve gayrimeşru ilişkinin gözlerden uzak yapılmasına imkân sağlayan mekan olarak görülmektedir (Foucault, 2011:300)

Son heterotopya ise, iki aşırı uç arasında yer alan ve yanılsama yaratan heterotopyalardır. Bunlardan biri dini kolonilerin dinsel amaçlarla gerçekleştirmiş oldukları mekân ve yaşam biçimi heterotopyasıdır. Diğeri ise öteki uçta yer alan genelevlerin oluşturduğu heterotopyalardır (Foucault, 2011:301). Foucault ütopya ile heterotopya arasina karma bir deneyim alanı olan aynanın var olduğunu düşünmektedir. Foucault'ya göre;

"Ayna sonuçta bir ütopyadır; çünkü yeri olmayan yerdir. Aynada kendimi olmadığım yerde görürüm, yüzeyin ardında sanal olarak açılan gerçekdışı bir mekanda görürüm, oradayımdır, olmadığım yerde, kendi görünürlüğümü bana veren, olmadığım yerde kendime bakmamı sağlayan bir tür gölge"' (2011:295).

Ancak Foucault aynanın aynı zamanda bir heterotopya olduğunu ifade etmektedir. Aynada kendini orada gören bulunduğu yerde olmadığını da bu anlamda keşfetmektedir. Ancak bakıştan yola çıkarak bakışın sahibine yönelmesiyle birlikte varlığı tekrar bulunduğu yerde inşa etmeye başlar (Foucault, 2011:296). İşte bu nokta, hem gerçek, hem de gerçekdışının bir arada olduğu ayna heterotopyası gerçekleşir. 
Heterotopyaya geçiş mekânı olarak eşikler önem kazanmaktadır. Eşikte olmak, arada kalmış olmayı, kimliksiz olmayı ve kısa bir süre için özgürleşmeyi ifade etmektedir. Eşik, iki mekânsal düzey arasında bir geçiş alanıdır. Kimliklerini belirleme hakkını kendilerinde görenler, eşikte olmaya cesaret göstermektedir. Eşiktelik, bir geçiş kimliği olmasına rağmen, yine de bir kimliktir (Stavrides, 2018:227-228). İki farklı mekân arasında geçiş yeri olan eşikler öteki ile normal olanı ayırmanın koşulu olarak ortaya çıkmaktadır. Kapılar, köprüler, pencereler iki farklı mekân arasında geçişi sağlayan eşikler olarak değerlendirilebilir. Her eşik bir önceki kimliği askıya alarak yeni bir kimliğe geçişe hazırlık aşamasıdır. Yeni bir kimliğe geçmek ötekiliğe geçişi ifade etmektedir. Böylece ötekilik sadece mekânsal bir ötekilik değil, zamansal olarak şimdiden kopmayı sağladığı için zamansal ötekilik olarak da değerlendirilebilir (Stavrides, 2016:18).

\section{Çalışmanın Amacı}

Sinemanın da bir heterotopya olduğunu düşünen Foucault, öznenin hem kendine yeni bir heterotopya oluşturmasında hem de yeni heterotopyalar keşfetmesinde sinemayı önemli bir konuma yerleştirmektedir. Bu çalışma, bir öteki mekân temsili olarak heterotopyalara odaklanırken sinemada heterotopyanın kullanım biçimi olarak L'Amant Double (Tutku Oyunu, Francois Ozon, 2017) filminde yer alan heterotopik mekân unsurlarını incelemektedir. İktidarın gücünü mekân üzerinden biçimlendirmesi, ötekilik mekânı olarak heterotopik mekânların oluşmasına neden olmaktadır. Bir ötekilik mekânı olan ve ütopyalara geçişte ara bir mekân olan heterotopya, modern insanın kendine oluşturduğu bir kaçış mekânıdır. L'Amant Double filmi, Chloe'nin karın ağrısı şikâyeti ile başlayan ve farklı heterotopik mekânlar arasında gerçekleşen, ütopyaya ulaşma arzusunu anlatmaktadır. Bu kapsamda L'Amant Double filmi, Foucault'nun heterotopya kuraminda yer alan sapma heterotopyaları olarak Psikiyatri Kliniğine, zaman heterotopyaları olarak müzelere ve ayna heterotopyasına yer vermektedir. Filmde eşik mekânları olarak köprülerin kullanılması ve olmayan yer olarak aynaya sıkça yer verilmesi, çalışmanın örneklemi olarak L'Amant Double, (Tutku Oyunu) filminin seçilmesinde etkili olmuştur. Bu çalışma, heterotopyayı bir öteki mekân temsili olarak incelerken, heterotopyanın sinemada evrilen biçimlerini açığa çıkarmayı amaçlamaktadır.

\section{Çalışmanın Yöntemi}

L'Amant Double filmini, ötekilik temsili olarak heterotopya bağlaminda inceleyen bu çalışma, Foucault'nun heterotopya kuraminı temel almaktadır. Foucault'nun heterotopya kuraminda yer alan sapma heterotopyası, zaman heterotopyası olarak müzeler ve ayna heterotopyası çalışma kapsamına alınarak inceleme kategorileri olarak belirlenmiştir. Stavrides'in Kentsel Heterotopya çalışmasına temel aldığı eşikler ise heterotopyaya girişe imkân tanıyan geçiş mekânları olarak görülmektedir. Bu kapsamda çalışmada heterotopya alanlarına girmeyi sağlayan geçiş mekânları olan bekleme odaları, köprüler incelemeye alınan kategoriler arasına yerleştirilmiştir. Çalışmanın yöntemi olarak Foucault'nun heterotopya kuramı ile Stavrides'in eşikler kuramı temel alınarak film sahneleri heterotopya kategorileri bağlamında incelenmiştir.

\section{L'Amant Double Filmi Hakkında}

L'Amant Double Fransızca Çifte âşık olarak çevrilen ancak Türkiye'de Tutku Oyunu olarak vizyona giren film, 2017 yılında François Ozon tarafından yönetilmiştir. Ozon, Joyce Carol Oates'ın Lives of Twins adlı romanından etkilenerek sinemaya uyarladığ filmi, zihinsel bir hikaye olarak adlandırıyor. Ozon, hikayenin merkezine yerleştirdiği Chloe ile gerek mimari düzen, gerek yansımalar ve geometrilerle oynayarak filmini yönettiğini ifade etmektedir (www.baskasinema.com). Film, Chloe adında genç bir kadının karın ağrılarına fiziksel çözüm bulamaması üzerine psikiyatriste gitmesiyle başlamaktadır. Psikiyatrist Paul Meyer'in terapileri ile düzelmeye başlayan Chloe, aynı zamanda bir aşk ilişkisi içerisinde kendini bulur. 
Aynı eve taşınarak yeni bir hayata başlayan Chloe, taşınma eşyaları arasında Paul'a ait başka bir kimlik ile karşılaşınca işler değişmeye başlar. Paul ikizi olan Louis'i Chloe'den saklar ve Chloe kendi yöntemiyle ikizinin psikiyatri kliniğine gider ve Louis'in terapilerine katılır. İkiz psikiyatr kardeşlerin (aşk ve cinsellik) arasında kalan Chloe, zihinsel gel-gitleri ve değişen ruh halleri ile birlikte huzursuzluğunu gidermeye çalışırken, heterotopik mekânlar filmde dikkat çekmeye başlar. Chloe'nin tekrarlayan karın ağrılarına karşı çözüm üretmek için gittiği psikiyatri klinikleri, ruh haline göre değişen müzede sergilenen nesneler, eşik mekânları ve aynalar filmi mekân bağlamında öne çıkarmaktadır.

\section{L'Amant Double Film Analizine Ait Bulgular}

L'Amant Double filmi üç ana karakter ekseninde ilerlemektedir. Bu karakterler, karın ağrısı şikâyeti ile tanıştığımız Chloe, bu şikâyetini gidermek üzere yönlendirilen Psikiyatr Paul Meyer ve onun ikizi olan ancak tamamen zit karakterlere sahip olan Louis Delord'dur. Film analizi yapılırken Foucault'nun heterotopyaları temel alınarak bu heterotopyalardan Sapma Heteropyası Olarak Psikiyatri Klinikleri, Zaman Heterotopyası Olarak Müze, Ayna Heterotopyası ve Heterotopyalara Geçiş Mekânı Olarak Eşikler inceleme kategorileri olarak belirlenmiştir.

Filmin temelinde Chloe karakterinin yaşadığı karın ağrıları dikkat çekerken diğer tarafta sıkça konuşulan ikizlik ve yamyam ikizler kavramı izleyiciye sunulmaktadır. Film, yamyam ikizler kavramına sık sık gönderme yaparken, ikizlik meselesi ile olan ilişkisi dikkat çekmektedir. Yamyam ikizler kavramı, anne karnında güçlü olan ikizin diğer ikizi yok etmesi üzerine şekillenmektedir. Tip dilinde ikizlerden birinin diğerini yemesi gibi bir durum söz konusu olmasa da bu duruma benzeyen vakaların gerçekleştiği de görülmektedir. Tip literatüründe The "Vanıshıng Twın" Syndrome, ikiz gebeliklerde bebeğin birinin kaybedilmesi olarak tanımlanır (Kovachev ve ark., 2015: 853). Bunun yanında ikizlere ait bir başka iz, 20'li yaşlarda görülen dermoid kistlerdir. Bu kistler embriyolojik gelişim döneminde bir anomaliye bağlı olarak ortaya çıkmakta ve içeriğinde kıl folikülleri ve ter bezleriyle birlikte matür deri, bazen uzun saç yumağı, kan, yă̆, kemik tırnak, diş, göz, kıkırdak ve tiroid dokusu bulunmaktadır (Eroğlu ve ark., 2010:348-349). Yani bu kistler, yamyam ikizler teorisini akla getirecek türden bilimsel alt yapıyı hazırlamaktadır. Filmde Chloe'nin karın ağrılarının temel sebebi olan bu kist, filmin doruk noktasında yalancı bir gebelik olarak karşımıza çıkar. Bu anlamda film, Chloe karakteri ve onun karın ağrısı üzerinden ilerlerken, ruhsal gerilimlerini ve zihinsel gelgitlerini izleyiciye aktarmaktadır. Film, Chloe'nin saçlarını kestirme sahnesi ile açılmaktadır. Bu sahne, Chloe'nin saçlarını kestirmesi ile psikolojik problemleri arasında doğrudan bir ilişki kurmayı kolaylaştırmaktadır. Filmin ikinci sahnesi bir jinekolojik muayeneyi izleyiciye sunar ve doktorun Chloe'ye fizyolojik bir sorunu olmadığını ve psikoloğa gitmesi gerektiğini söylemesi ile ilerler. Filmde Chloe'nin psikolojik sorunları çerçevesinde gelişen mekânsal değişimler heterotopik alanlar olarak değerlendirilmektedir.

\section{Sapma Heteropyası Olarak Psikiyatri Kliniği}

Bir sapma heterotopyası olarak psikiyatri klinikleri, ruhsal bozukluğu olanları bir araya getiren heterotopik mekânlardır. Toplumsal yaşama ayak uyduramayanlar, psikolojik problemlere sahip olanlar için sapma heterotopyaları, bireylerin yaşama entegre olmaları için terapi imkanı sunmaktadır. Hapishaneler, tımarhaneler ve psikiyatri klinikleri bireylerin sapma davranışlarına sahip olmaları durumunda kurumlar tarafından yönlendirilerek kapatıldıkları mekânsal alanlardır. Foucault'nun "Deliliğin Tarihi (Madness and Civilization)" ve "Hapishanenin Doğuşu (The Birth Of The Prison)" adlı eserleri toplumdan dişlanan deli, cüzzamlı ve suçlular üzerine odaklanmaktadır. Bu eserler, toplumsal yapıya uygun hareket etmeyen insanların iktidar tarafından cezalandırılmasını ve değişen cezalandırma biçimini aktarmaktadır. İktidar olan kralın suçluyu halkın gözü önünde cezalandırma uygulamasında adaletin yerine getirilmesinden çok iktidarın gücünün dişavurumu görülmektedir. (Foucault, :2017 95) Hapishanenin Doğuşu eserinde Foucault, mahkumlara halkın önünde yapılan 
işkencelere ve kötü muamelelere yer verir. Ölüm cezası infaz edilirken, mahkuma azap edilmesi kabul edilmeyen bir durum olarak görülmektedir. Ancak halk, zamanla mahkuma yapilan işkencelere karşı direniş göstererek bu tip cezalandırma sisteminin ortadan kalkmasında rol oynamıştır (2017:114). XIX. Yüzyıl bu anlamda mahkûmların hapishane çatısı altında toplumsal düzene uyan bir özneye dönüşmesine neden olmuştur. Buna göre hapishanenin doğuşu, "ruhun, bedenin terbiye edildiği, şekillendirildiği, işlendiği ve üzerine yatırım yapıldı̆̆ normatif ve normalleştirici bir ideal halini aldığı, altında bedenin maddileştiği tarihsel olarak özel bir imgesel ideal" (Butler, 2015: 92) olarak dikkat çeker.

L'Amant Double filminde sapma heterotopyaları Chloe' nin yaşadığı karın ağrılarından kurtulmasını sağlayacak olan ikiz kardeşlerin psikiyatri klinikleri olarak yer almaktadır. Paul ile Chloe'nin ilk terapi seansı aynı zamanda Chloe'nin yaşamına ve kişiliğgine ait bilginin izleyiciye sunulmasını da sağlamaktadır.

"Yirmi beş yaşındayım. Yalnız yaşıyorum. Yani tam olarak değil. Kedim Miloyla yaşıyorum. Şu anda iş arıyorum, bu çok zor. Ben stresliyim, yanlış şeyler söylüyorum, işi berbat ediyorum. Gençken çok daha iyi kazanıyordum. Modellik yapıyordum. Ama bıraktım, birkaç sevgilim oldu, önemsiz ilişkiler. Sanırım benim sevme yeteneğim yok. Bazen içimde bir boşluk oluyor. Bir şey eksik sanki. Bazen nedensiz yere ağhlyorum....bana yardım edebilecek misiniz?"

Chloe'nin filmin başlarında kendini Paul'a tanıtmaya başladığı aşamada onun iş aradığını ve çok stresli olduğunu ifade etmesi, modern kent yaşamında insanların kendilerini güvende hissetmeyerek yeni mekân arayışlarına sürüklediğini göstermektedir. Chloe de bu modern yaşamın stresinden nasibini almış ve iş aramanın ve bulamamanın vermiş olduğu stresli yaşam onun kendini psikiyatri kliniğinde bulmasına neden olmuştur. Heterotopyanın oluşumunda öznenin biyo-iktidarın içine tam olarak yerleşmemesi ve topluma aykırı kişilik yapısı nedeniyle toplumdan uzaklaşma ile yaşamın yeni bir mekânda devam etmesi sağlanmaktadır. Bireyin kendine heterotopik mekân oluşturmasında modern yaşamın insanı sınırlayan ve sınıflandıran yapısı dikkat çekmektedir. Çünkü birey bu yaşam biçimi içinde çalışarak var olmakta aksi takdirde stresli bir yaşamın kıyılarında gezinmektedir. Chloe'nin sadece iş bulamaması değil, yalnız olması ve hayatında sevebileceği birini bulamaması da onun hayatında eksiklik ve boşluk hissi yaratmaktadır. Bu boşluk hissi onun hem iş bulmasıyla hem de âşık olmasıyla doldurulacaktır. Biyo-iktidar, özneyi inşa ederken, onun toplum ile uyumlu bir birey olmasını da sağlamaktadır. Oysa Chloe, psikiyatr ile olan konuşmalarında bahsedeceği üzere annesi ile uyumlu manada gelişemeyen ilişkileri, onun topluma entegre olamamasında önemli bir sebep olarak dikkat çekmektedir. Chloe'ye uygulanan terapi seanslarının hayatına olumlu manada eşlik etmesi; metaforik karın ağrısının ortadan kalkması ile anlaşılmaktadır. $\mathrm{Bu}$ anlamda modern insanın kendisini dinleyecek birini ya da birilerini bulamaması sapma heterotopyası olarak kliniklerin bu işlevi sağlamada önemli rolü olduğunu göstermektedir. Böylece birey, kendisini en ince ayrıntısına kadar aktararak sorunlarına çözüm yolu sunma noktasında klinikleri heterotopya haline getirmektedir.

Filmde Paul, Chloe'yi daha iyi tanımak ve kişiliğini çözümlemek için geçmiş yaşamına ait bilgileri öğrenmek ister. Chloe'nin geçmişinde annesiyle bağlarının zayıf olması ve büyükannesinin onu büyütmesi, anneye karşı düşmanca hisler geliştirmesine ve onu rakip olarak görmesine neden olmuştur.

"Modellik yapmaya başladı̆̆ımda bu heyecanlıydı. Sonra bayalı̆̆ılaştı. Küçükken aktrist olmak istiyordum. Cezbedici olmak istedim. Çeoremdekileri ayartmak istiyordum. Özellikle de yetişkinleri... Annemin arkadaşların onlarn ilgisini çekmek isterdim. Ama bana dokunmaları hoşuma gitmiyordu. Ben gerçekten çok utangaçtım ve uyumsuzdum."

Chloe'nin narsistik eğilimi onun annesine olan düşmanca hislerinin kendi bedenini yücelterek onu insanların arzulama isteği içinde olmasıyla anlaşılır hale gelmektedir. Chloe' nin geçmişten gelen çevredeki insanları ayartma isteği ve gençlik yıllarında modellik yapma heyecanını içinde yaşaması, bir süre sonra bu isteğinin de sıradanlaşmasına neden olmuştur. Chloe, içinde sevgi nesnesini sadece kendisine yönelterek, herkesin onu arzuladığı 
biri haline gelmesini sağlamıştır. Bu durum ise onun içindeki boşluk hissini giderememiştir. Freud'un Narsisizm Üzerine adlı eserinde ilk sevgisi nesnesinin anne sevgisi olduğunu ifade etmektedir (2012:35). Freud bunu birincil narsisizm olarak adlandırmaktadır. İkincil narsisizm, kız çocuğunun ilk nesne olan anne sevgisini tekrar oluşturamamasıyla öfke duygusunu bastırarak, güzellik ile kendi beninin yüceltilmesine neden olmaktadır. Chloe de içindeki anne sevgisini yönelteceği bir anne imgesi yerine kendi benini yücelten bir kadına dönüşmüştür.

Film boyunca çevresinde gezindiğimiz ikizlik meselesi Chloe'nin çocukluktan itibaren hayal ettiği ve asla sahip olamayacağı bir yanılsamadır.

"Hep bir kız kardeş hayal etmişimdir. Bi ikiz, bir kardeş, her zaman beni koruyacak..."

İkize sahip olma Lacan'ın ayna evresi ile ilişkili okunabilir. Ayna evresine göre aynada çocuğun kendini tanıması üç aşamada gerçekleşir. İlk aşamada aynanın önünde annesiyle duran çocuk kendi varlığı ile annesinin varlığının farkına varamaz ve iki kişiyi bir olarak görür. İkinci aşamada aynadaki yansımanın bir imge olduğunu ve gerçek olmadığını fark eder. Üçüncü aşamada ise aynada beliren kendi imgesinin ötekinin imgesinden ayrı olduğunu anlar (Sarup, 2017: 25). Chloe için bir nefret simgesi olan anne yerine ayna evresinde bir ikizi olmasını düşler. Böylece kendi varlığını koruyacak ve her daim yanında olacak anne yerine ikizini arzulamaktadır. İkizi arzularken, ayna evresi ile olmayan yerde gördügü kendi imgesi ile bu istek giderilmeye çalışılmaktadır. Annenin çocuğu koruyucu ve kollayıcı tavrını Chloe, filmde olmayan ikizine yansitmaktadır.

Chloe'nin psikiyatri kliniğine gitmeye başlaması yani tedavi arayışı onun müzede çalışmaya başlamasını da sağlamıştır. Foucault'nun heterotopya kuramında yer alan müzenin Chloe'nin iş yeri haline gelmesi, Chloe karakterinin filmde heterotopik mekânlar arasında gelişen yaşamını göstermektedir. Chloe, Paul'un psikiyatri kliniğine giderek özgüven kazandığını ifade etmektedir. Bu anlamda Chloe ile Paul arasında terapi seansları işe yarar ve Chloe'nin karın ağrısı şikayeti ortadan kalkarak kendini mutlu hissetmeye başlar. Ancak bu noktada, Chloe' nin iyileşmekten korktuğunu, zayıf kalmak istediğini ve güçlü olmaya çalışırken acı çektiğini ifade etmesi, onun psikiyatri kliniğine olan bağlılığını ve hasta olma halinden kurtulmak istemediğini göstermektedir. Bu durum psikiyatri kliniğinin bir heterotopya olmasını da anlamlı kılmaktadır. Aslında Chloe, iyileşmeyi değil, sancılı bir bedene sahip olmayı istemektedir. Zaten film boyunca yinelenen karın ağrıları onun zayıf psikolojisinin kırılgan noktalarına gönderme yapmaktadır. Chloe karın ağrıları olduğu dönemde yani psikiyatri kliniğine giderken maskülen kıyafetler giymeyi tercih etmesine karşın, terapilerin işe yaraması ve Paul'a âşık olmasıyla birlikte daha feminen bir giyim tarzı ile görünmektedir. İkiz kardeşlerin bir diğeri Louis Delord'dur. Farklı iki mizaca sahip olan ikiz kardeşler aynı bedene sahip oldukları gibi aynı mesleği seçip aynı okullarda okumuşlardır. Louise ikizi olan Paul ile olan farklılıklarını şu cümlelerle ifade eder.

"Ben iki buçuk kilo doğdum, o iki kilonun altında. Ben onun abisiyim. On beş dakika önce doğdum. Ben baş tarafindan doğdum oysa o bacak tarafindan gelmiş ve annem çok acı çekmiş, çok kan kaybetmiş. Ben să̆ elimi kullanıyorum, o solak. Onun sol gözü zayıftır, benim să̆. Biz tek yumurta ikiziyiz. Bazı ilkel toplumlarda ikizlerin tekini öldürürler. Çünkü hayatta kalma şansı daha azdır."

Bir başka sahnede Louis, Paul'un onu kabul etmeme durumunu şu sözlerle aktarır.

"Biliyorum, o ikizi olmasına hiç dayanamadı. Varlı̆̆ımı reddediyor. O özel olmak istiyor. Yegâne çocuk annesinin bir tanesi. Ben onun için yokum."

Freud'cupsikanalitikeleştiriyapıldığındaikizlerinidvesüperegolarıilekarşılaşılmaktadır. İd, kişiliğin biyolojik yönünü ifade eder ve toplum tarafından açığa vurulduğunda hoş karşılanmayan cinsel ve saldırgan dürtüleri tanımlar. Süperego ise kişiliğin toplumsal yönünü oluşturur ve ahlaki amaçlar, saldırgan dürtülerin baskılanması gibi kişiliği kusursuz olmaya yöneltir (Geçtan, 2014:46). Paul süperegoyu, baba otoritesini yani uygarlığa girişi temsil etmektedir. Oysa Louis, saldırgan cinselliği ile bilinçaltında kalan dürtülerin kaynağı olarak 
gösterilmektedir. Bu anlamda ikizler, tek bedenin iki tamamlayıcı yönü olarak düşünülebilir. Film boyunca bahsi dönen ikiz kavramı ve yamyam ikizler bu anlamda psikiyatri mesleğiyle ilgilenen iki kardeşin iki farklı mizaca sahip olmasını da anlamlı kılmaktadır.

Filmde kullanılan bir başka sapma heterotopyası Louis' in psikiyatri kliniğidir. Yukarıda bahsi geçtiği üzere Louis, ikizi Paul'un bilinçaltını şiddet ve cinselliğin bir arada olduğu idi temsil etmektedir. İkiz kardeş hikâyesinin peşine düşen Chloe, karın ağrısı şikâyeti ile Louis Delord'un psikiyatri kliniğine gider. Chloe karakterinin zihinsel ve biyolojik kırılganlığını ifade eden hasta olma hali ve bundan kurtulmaya yönelik teşebbüsler, her iki psikiyatr tarafından farklı şekillerde terapi yöntemleri ile giderilmektedir. Chloe' ye sert davranmasına ve onu yalancı olarak nitelendirmesine karşın, Chloe, Louis'in kliniğine gitmekten kendini alıkoyamaz. Chloe Louise'i, Paul ile gideremediği cinsel hazların tatmin eden bir avatar olarak görmektedir (www.baskasinema.com). Başlangıçta merakını gidermek için Louis Delord'un kliniğine giden Chloe, zamanla bu yasak ilişkiden kendini alıkoyamaz. Bu anlamda, içten içe sevgilisi Paul'u aldatmaktan rahatsızlık duysa da sürekli gittiği Louis'in psikiyatri kliniği Chloe için bir heterotopya haline gelmektedir. Paul ile yaşadığı aşk ilişkisinde eksik kalan şiddetli cinselliğin sağaltımını Louis' in kliniğinde yaşamaktadır. Bu nedenle Chloe için her iki psikiyatri kliniği ona iyi gelen iki farklı dürtülerin tatmin edilmesini sağlamaktadır. Chloe hem fizyolojik hem de psikolojik ihtiyaçlarının tatmini için kendine heterotopik mekânlar oluşturarak varlığın bir başka mekânda imkânını gerçekleştirmektedir. Heterotopya bu dünyada var olan bir mekân olarak, özneye açık kimlikler sunarak bir özgürleşim alanı yaratmaktadır. Chloe için mutluluk her iki heterotopyanın bir arada var olmasını arzuladığı bir ütopya haline gelmektedir.

\section{Zaman Heterotopyaları Olarak Müze}

Filmde zaman heterotopyaları olarak müzeler dikkat çekici bir şekilde kullanılmaktadır. Zaman heterotopyaları geçmişi biriktirerek bir kültürel bellek işlevi görmektedir. Zaman heterotopyaları olarak müzeler ve kütüphaneler biriktirme, arşiv oluşturma ve bütün zamanları bir arada tutma düşüncesini içeriğinde taşımaktadır (Yılmaz 2018: 57). Filmde ise müze, Chloe' nin zihni gibi işlev görmektedir. Chloe'nin iş yaşamını oluşturan müze, insanları takip ederken zihninde işlediği ve ona ait nesneler ile anlam kazandığ 1 bir heterotopyaya dönüşmektedir. $\mathrm{Bu}$ anlamda heterotopik bir alan olarak müze, geçmişi biriktirmek yerine onun zihnine ait kurgusal ürünleri biriktiren bir heterotopya halini almaktadır. Chloe'nin yarı zamanlı olarak çalışmaya başladığı müzedeki görevi takipçiliktir. Chloe yaptığı iş ile ilgili düşüncelerini Paul'a aktarırken, insanları takip etme noktasına takılıp kalmıştır.

"İnsanlarn takip etmek gariptir ama neyse ki orası bir müze, hapishane değil..."

Chloe'nin insanların müzedeki davranışlarını takip etme olarak tanımladı̆̆ı yeni işini bir tür hapishanede insanların davranışlarını gözlemleyen gardiyanlara benzetmektedir. Hapishaneye nazaran bir müzede çalışıyor olmasından hoşnut olmasına karşın, insanların davranışlarını takip etmeyi komik bulmaktadır. Farklı bir heterotopya olan hapishane, sapkın davranışa sahip olanların yerleştirildiği disipline dayalı mekânlardır. Chloe'nin müzede çalışmaya başlaması ile onun ruh halinin değişimi müzede sergilenen nesneler üzerinden aktarılır. Chloe için müze, yeni bir hayata başlamayı imlerken, aynı zamanda ruh halinin değişimini zamana bağlı olarak sergilenen nesneler üzerinden gösterir. Chloe'nin ilk iş gününde müzenin beyaz görüntüsünün içinde havada asılı beyaz balonlar dikkat çeker. 


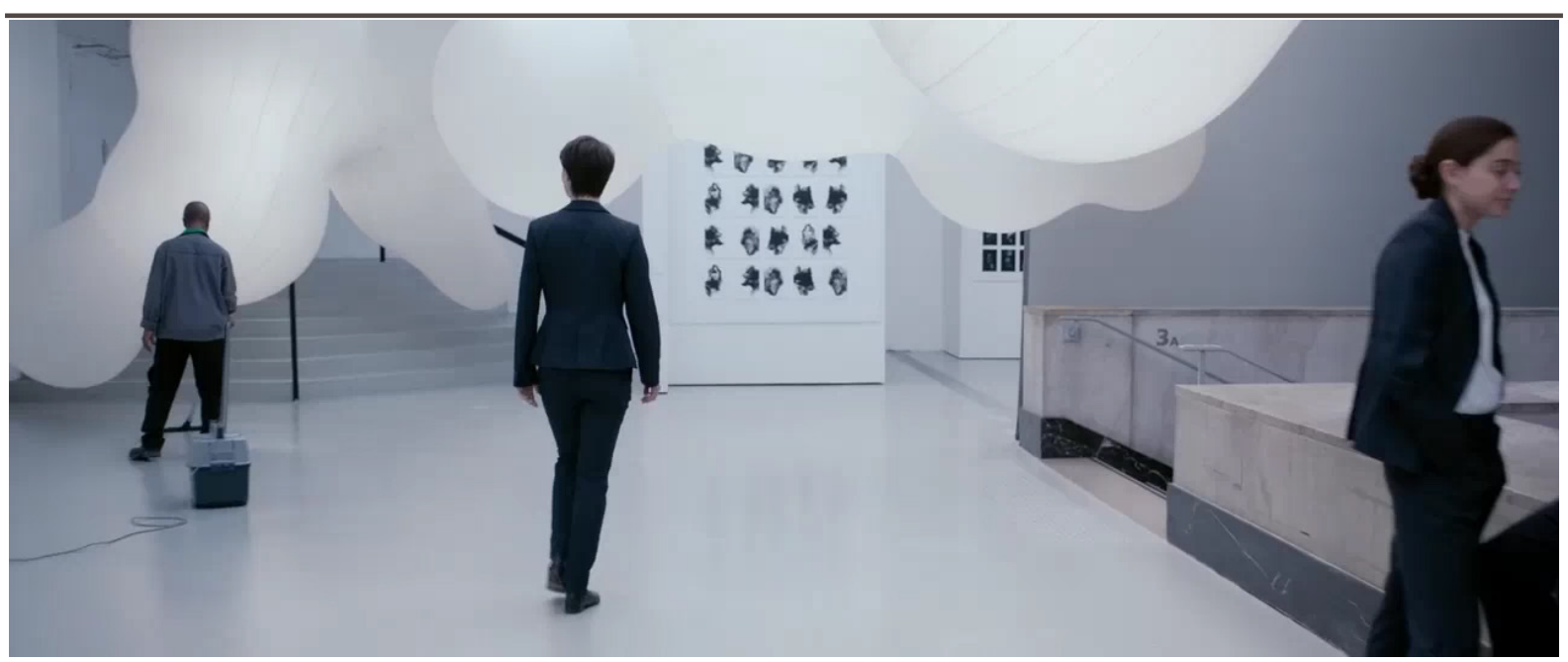

Görsel 1: Müze Heterotopyası: Beyaz Balonlar

Müzenin duvarında sergilenen yirmi adet kurt görseli ve Chloe'nin her iki yanında mutlu çocuk tabloları bulunmaktadır. Chloe'nin karın ağrısından kurtulması ile beyaz balonlar arasında analoji kurulmaktadır. Chloe'nin mutluluğu çocuksu bir mutluluk olarak belirmektedir. Chloe'nin Paul'un evine taşınmasının ardından eşyaları arasında Paul Delord'a ait bir pasaporta ulaşması ile Paul'a bunun ne anlama geldiğini sorar. Paul geçmişinin kurcalanmasından rahatsız olur ve işe ilk başladığında annesinin soyadını kullandığını söyler. Ancak Chloe, Paul'un açıklamalarını gerçekçi bulmaz. Chloe' nin Paul'un geçmişine ilişkin sakladığı gerçekler ona huzursuzluk verir. Ertesi gün müze girişinde yer alan iki ayrı billboardda Chloe' nin huzursuzluğuna eşlik eden Flesh (et) ve Blood (kan) yazıları ve görselleri dikkat çeker. Chloe müzeye girer ve bir koridor boyunca sıralanmış Blood görselleri arasında yürür. Paul'un geçmişine ait hiçbir şey bilmemesi ve Paul'un onun hayatına dair her ayrıntıyı bilmesi Chloe' yi rahatsız eder. Bir önceki müze görselinde balonlar ile kaplı olan sergi salonu burada yerini kan ve et görsellerine bırakır. Balonun temsil ettiği saflık ve çocuksuluk ölümü ve hastalığ1 temsil eden kan ve ete yerini bırakır. Müze içinde yer alan görsellerde beyaza karışmış kan lekeleri resmedilmiştir. Bu görsellerde kullanılan, saflığa dokunan kan lekeleri Chloe' nin zihin dünyasının karışıklı̆̆ının bir metaforu olarak okunabilir.

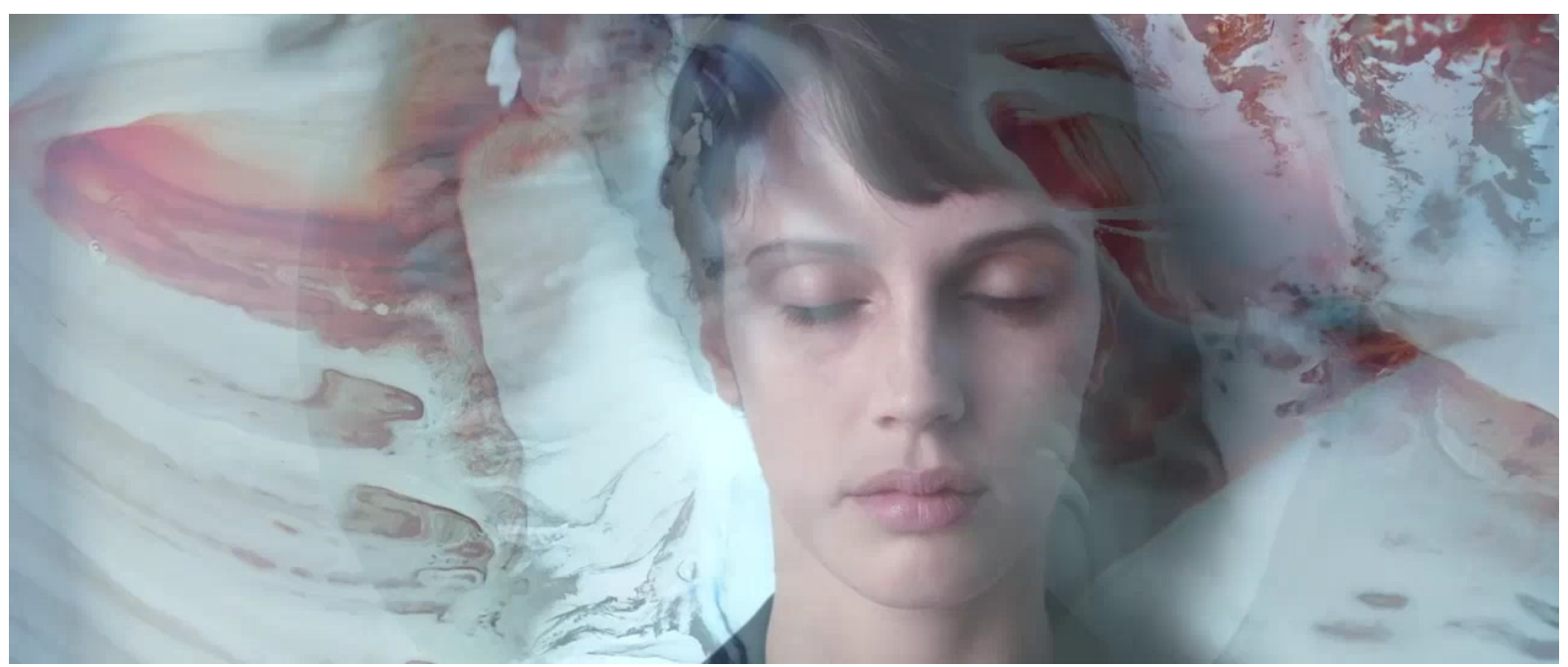

Görsel 2: Müze Heterotopyası: Saflı̆̆a Dokunan Kan Lekeleri

Chloe, Paul'un kendisinden bir şeyler gizlediğini hisseder ve bu işi kendi yöntemleri ile çözmeye karar verir. Chloe, Paul ile kadını birlikte gördügü binanın önüne gelir ve Louis Delord'un kliniğinin isminin yazılı olduğu yerin fotoğrafını çeker. Müzenin üçüncü günü izleyiciyi kökleri gökyüzüne uzanan beyaz bir ağaç gövdesi karşllar. Müze içinde telefon görüşmesi yaptığı esnada müzeyi boydan boya kaplayan ters ağaç imgesi, Louis ve Paul'un 
iç içe geçen karmaşık hikâyesini düşündürür. Ağacın dalları yerine köklerinin havada olması, çözülmeyi bekleyen girift bir yapıyı izleyiciye sunmaktadır. Bu girift yapı, Chloe' nin randevu almaya çalıştığı telefon sahnesi ile başlar. Chloe, Paul ve Louis arasındaki ilişkiyi çözmeye çalışırken, kendi ruh dünyası da bununla birlikte girift bir yapıya dönüşmüştür.

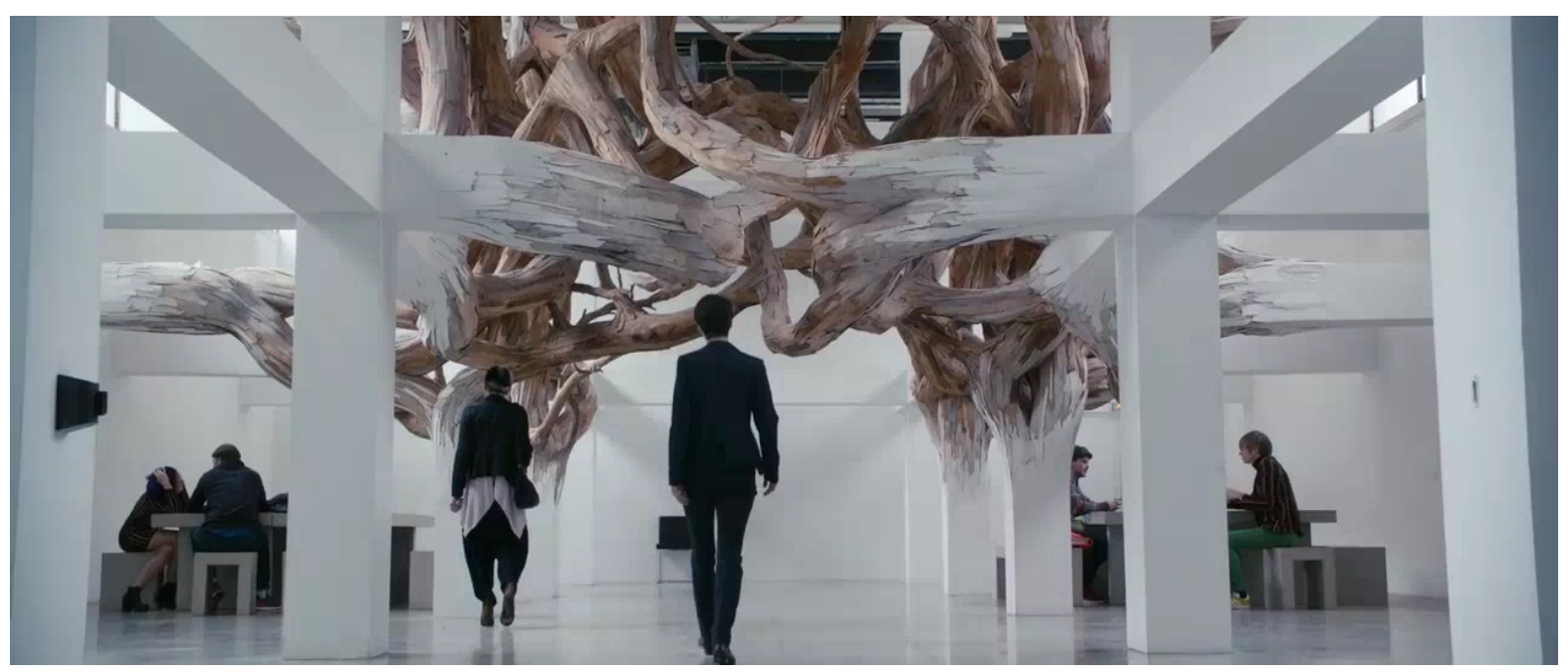

Görsel 3: Müze Heterotopyası: İ̧̧ İçe Geçmiş Kökler

Louis, Chloe'ye telefondan ulaşır. Chloe'ye "karnında benim bebeğimi taşıyorsun tarihlere bak" demesi üzerine Chloe telefonu kapatır. Müzeye geldiğinde fetüs görünümlü cisimler, izleyiciyi karşılar. Chloe' nin hamile olması ve içindeki bebeğin kime ait olduğuna dair kuşkularının olması ile bu sahne metaforik bağ kurmaktadır.

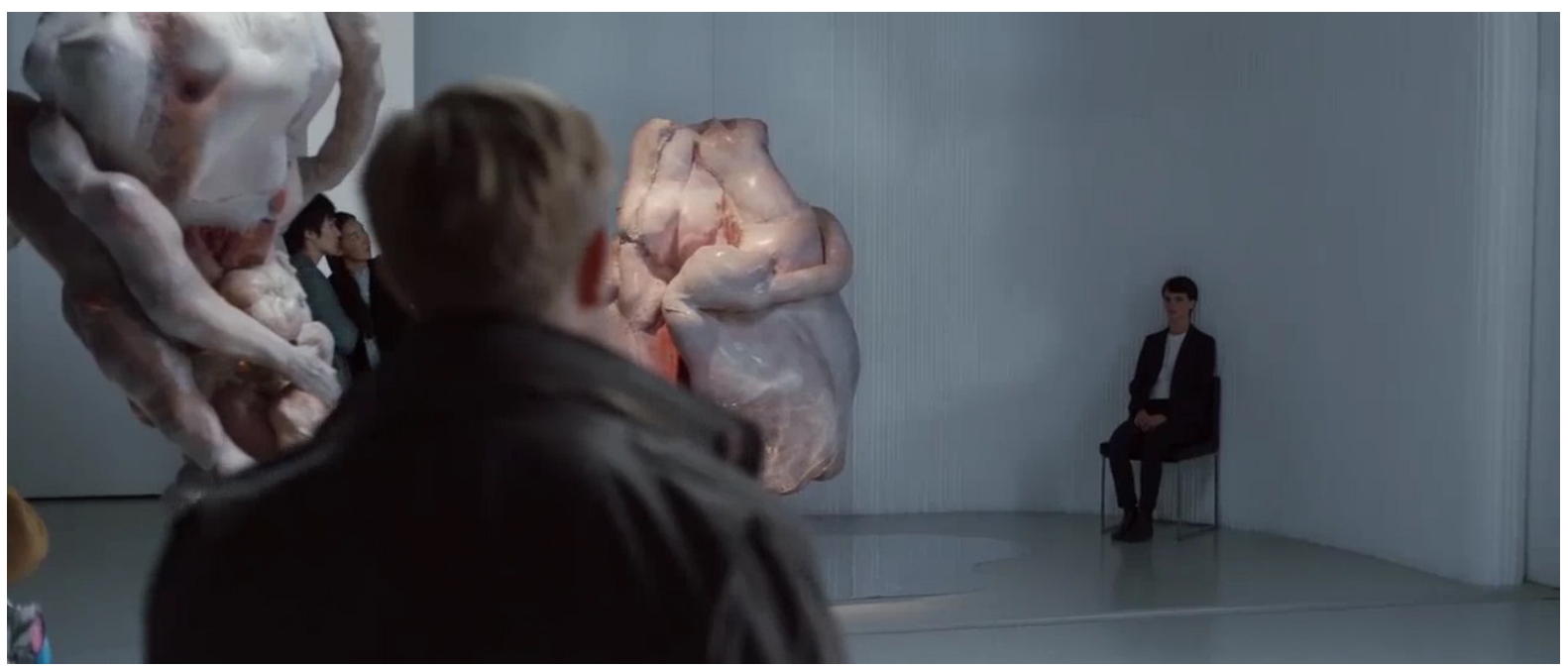

Görsel 4: Müze Heterotopyası: Fetüs Görselleri

\section{Ayna Heterotopyas1}

Heterotopya kuramında ayna imgesine yer veren Foucault, aynanın insanın kendini olmadığı yerde görmesini sağlayan bir heterotopya olduğundan bahseder.

“Ayna sonuçta bir ütopyadır; çünkü yeri olmayan yerdir. Aynada kendimi olmadı̆̆ım yerde görürüm, yüzeyin ardında sanal olarak açılan gerçek dışı bir mekanda görürüm, oradayımdır, olmadı̆̆ım yerde, kendi görünürlüğ̈̈mü bana veren olmadığım yerde kendime bakmamı sağlayan bir tür gölge: Ayna Ütopyası" (2011: 295).

Filmin yönetmeni Francois Ozon vermiş olduğu bir röportajda ayna ve sinema ilişkisinden şu sözlerle bahseder.

Aynaları severim, bir filmde kullanmak her zaman güzeldir. Çoğu zaman bir yansıma ve felsefi bir anlamı vardır. Aynalar birçok şeyi hayal etmenizi să̆lar (hiskind.com). 
Filmde sıkça kullanılan ayna imgesi, heterotopik alanlara geçiş mekânları olan eşiklerde ve heterotopik alanlarda kullanılmaktadır. Paul ve Louis ikiz kardeşlerin psikiyatri klinikleri sapma heterotopyası olarak kategorize edilmiştir. Ancak bu heterotopyalara geçiş mekânı olan koridorlar ve bekleme odalarında yer alan aynalar ise ayrı bir heterotopya kategorisi içerisine dâhil edilmiştir. Louis'in psikiyatri kliniğine giden koridor, dik aynaların kesiştiği ve soğuk mermerlerin zemini kapladığı bir şekilde tasarlanmıştır. Aynı anda altı aynada Chloe'nin yansıması ekranda görünür. Chloe, Louis'in heterotopik alanına geçerken bu aynalar ve aynalardan yansıyan Chloe imgeleri ile onun olmadığı yerde bir gölge olarak yansısı elde edilir.

Lacancı bakış açısıyla ayna, varlığın kendini ötekinin imgesinden ayrı olarak kurduğu aşamadır. Ancak ayna, yabancılaşma ve kopuşu da beraberinde getirmektedir.

Aynanın yaşama girmesi ile özne kendinden koparılır. Aynadaki imge beni daha ciddi bir başka yabancılaşmaya hazırlar. Bu da ötekilerin neden olduğu yabancılaşmadır. Çünkü ötekilerin benimle ilgili olarak tek gördükleri, ayna imgesine benzer bu dışsal imgedir (Akt. Çoban, 2005: 285).

Chloe'nin Louis Delord'un kliniğine giderken gördüğümüz aynadaki imgeleri, onun hem kendini yeniden tanımlamasına hem de yabancılaşmasına neden olmaktadır. Çünkü Chloe, Louis Delord'u tanımak ve kim olduğunu bilmek isterken kafasındaki soru işaretlerini giderme arzusu içindedir. Ancak kliniğin önünde yer alan aynalar ve bu aynalardan yansıyan imgeler, kimliğinin parçalanan iz düşümleri olarak görülebilir. Chloe, Louis'in kliniğine giderken Paul'a yalan söylemekte ve bu durum onun bedeninin ve ruhunun metaforik olarak parçalanmasına neden olmaktadır.

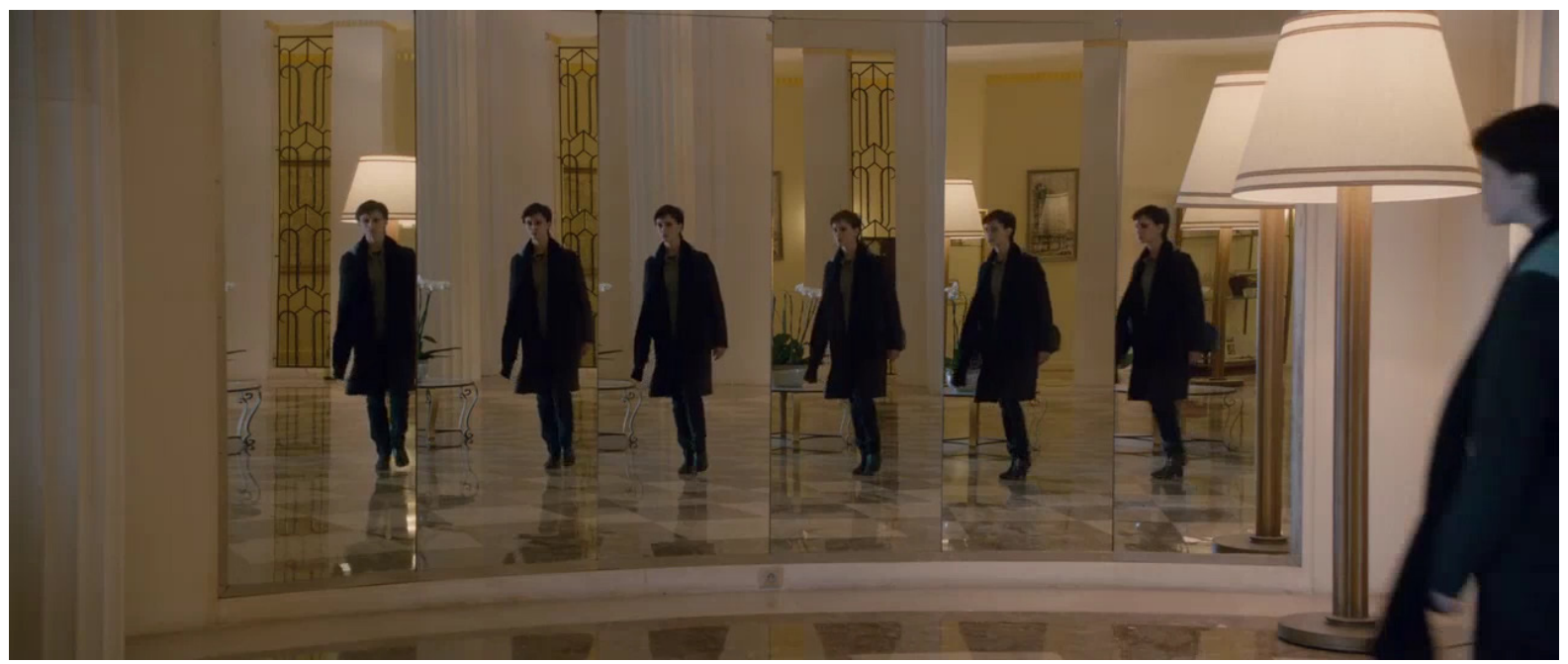

Görsel 5: Ayna Heterotopyası

Ancak bunun yanında Louis Delord, Chloe'nin kendisini yeniden tanımasını da sağlamaktadır. Chloe, Louis ile cinselliğinin farkına varmaktadır. Sonunda aynadaki imgeler, altı aynadan tek aynaya sabitlenir ve Chloe, aynadan yansıyan imgesinin gerçekliğini, gözünü silme eylemi ile onaylar. Böylece Chloe' nin yaşadığı yabancılaşma, tek aynada beliren imge üzerinden aktarılır.

Her iki psikiyatri kliniğinde de kullanılan ayna imgesi, karakterlerin mizaçlarına gönderme yapmaktadır. Paul Meyer'in kliniğinde kullanılan aynalar, yatay olmasına karşın, Louis Delord'un kliniğinde aynalar dikey kullanılmıştır. Yatay ayna imgesi, güven verici niteliğinin yanında durağanlığı ifade etmektedir. Paul Meyer'in daha sakin ve güven verici bir karaktere sahip olması, kliniğinde kullanılan ayna imgesiyle sağlamlaştırılmaktadır. Louis Delord'un Kliniğinde kullanılan dikey aynalar ise, mimaride iktidarı ve gücü çağrıştıran fallik imgesiyle düşünüldüğünde karakter ile uyumlu olduğu görülmektedir (Güngör, 92-93). Bir başka sahnede Chloe Paul'a ikiz bir kardeşin olsun ister miydin? sorusunu sorar. Paul ise "Hayır aynaya bakınca kendini görmek gibi olurdu" der. Aynaya bakınca kendini görmenin bir 
başka imkânı tek yumurta ikizlerinde yaşanmaktadır. Foucault’nun ayna imgesini, olmadığım yerde görünme olarak tarif etmesi, ikizler içinde geçerlidir. İkiz olma hali, bedenin aynı olan bedensel tasarıma ait olmadığını ve kendini ikizinin yerinde asla olmayacağını da gösterir.

\section{Heterotopyalara Geçiş Mekânı Olarak Eşikler}

Heterotopyalara geçişte eşikler, önemli bir işleve sahiptir. Eşikte olmak, iki alan arasındaki sınırda bulunmayı, arada kalmışlığı kimliksizliği ve kısa bir süre için özgürleşmeyi ifade etmektedir. Filmde Stavros Stavrides' in heterotopyalara geçiş mekânı olan eşikler dikkat çekici bir şekilde kullanılmıştır. Bu anlamda merdivenler, psikiyatri kliniklerinin bekleme odaları ve köprüler eşik mekânları olarak değerlendirmeye alınmıştır. Filmde kullanılan ilk eşik mekânı Chloe'nin Paul Meyer'in psikiyatri kliniğine ulaşmak için kullandığı merdiven sahnesinde görülmektedir.

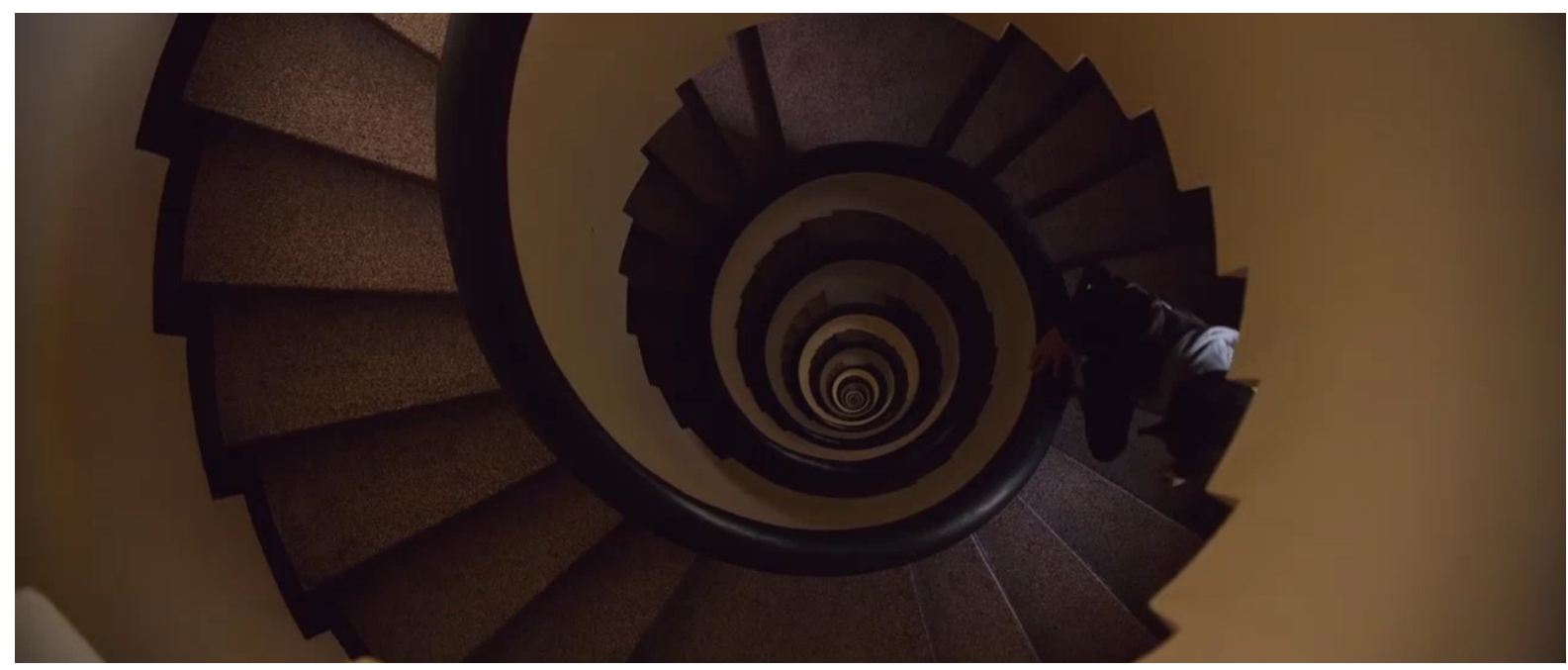

Görsel 6: Eşik Mekânı Olarak Merdiven

$\mathrm{Bu}$ merdiven sahnesi, vertigo efekti kullanılarak helezonlar oluşturacak şekilde sunulmaktadır. Chloe'nin içinde bulunduğu karmaşık durumdan dişarı doğru açılan görüntüyü, karanlıktan aydınlığa şeklinde okumak mümkündür. Stavrides'e göre eşikler, birbirine zıt iki farklı dünya arasındaki iletişim potansiyeliyle üretilir (2016:17). Eşik, içerisi ve dışarısı, normal ve öteki arasındaki geçişi sağlayan mekân olarak, Chloe'nin hastalıklı beden halinden evrildiği psikiyatri kliniğine geçişi sağlayan bir eşik mekânıdır. Bu anlamda filmde kullanılan merdiven sahnesi hem çıkma eylemini içinde bulundurmasıyla hem de içten dışa açılan görüntüsüyle ötekiliğe geçişi imlemektedir. Filmde ikizlerin psikiyatri kliniklerinin bekleme odası olarak tasarlanan mekânlar da geçiş mekânı olarak değerlendirilmektedir. Çünkü kliniklerin bekleme odaları ve bu odaların içindeki eşyaların konumlandırılması, ikizlerin (Paul ve Louis'in) ruh hallerini de açığa çıkarmaktadır. Paul Meyer'in psikiyatri kliniği, mavi renkli duvarların çevrelediği, rahat koltukların, beyaz orkidenin ve kitapların yer aldığı sıcak bir mimariye sahiptir. Paul Meyer' in kliniğinin bekleme odasında kullanılan mavi renk, onun güven verici niteliğini öne çıkarmaktadır. Mavi renk heterotopyaya geçişe aracılık eden eşik mekânında kullanılarak heterotopyanın güven ve sadakati sunacağını izleyiciye gösterir. Paul'un kliniğinin rahat ve davetkâr bir yapısı olmasına karşın Louis' in kliniği soğuk renklerin çevrelediği ve mermerin yoğun olarak kullanıldığı bir mimariye sahiptir. Her iki psikiyatriste ait bu mekânsal düzenlemeler, ikizlerin ruh halini de yansitmaktadır. Louis'in psikiyatri kliniği, daha koyu renklerin hâkim olduğu loş 1şıkların ortamı aydınlattığı daha kasvetli ve sert çizgilere sahiptir. Chloe koyu renkli bir koltuğa oturup beklerken solunda yapay beyaz bir orkide dikkat çeker. Chloe tıpkı Paul'un kliniğinde yaptığı gibi orkidenin toprağına elini sürer ve onun gerçek olup olmadığını test eder. Geçmişte orkidenin soğanlarının erkek testisine çiçeklerinin ise kadın cinsel organına benzemesi orkidenin kilise tarafından yasaklanmasına ve günah olarak nitelendirilmesine neden olmuştur (blog.milliyet.com.tr). 
Filmde iki ayrı klinik geçiş mekânında karşılaşılan orkideler, cinsellik çağrışımıyla ilişkili olabileceği gibi orkidenin saf ve gerçek aşk anlamını da akla getirmektedir. Orkidelerin yapay ve gerçek oluşları Paul ve Louis' in Chloe'ye besledikleri duygularının da bir iz düşümü olarak değerlendirilebilir. Paul'un saf aşkı ve duygusal cinselliğine karşın, Louis sevgiden yoksun vahşi cinselliği ile öne çıkmaktadır.

Filmde kullanılan bir başka eşik, köprü metaforudur. Filmde kullanılan köprü Chloe'nin yeni bir hayata başlangıcını ifade etmektedir.

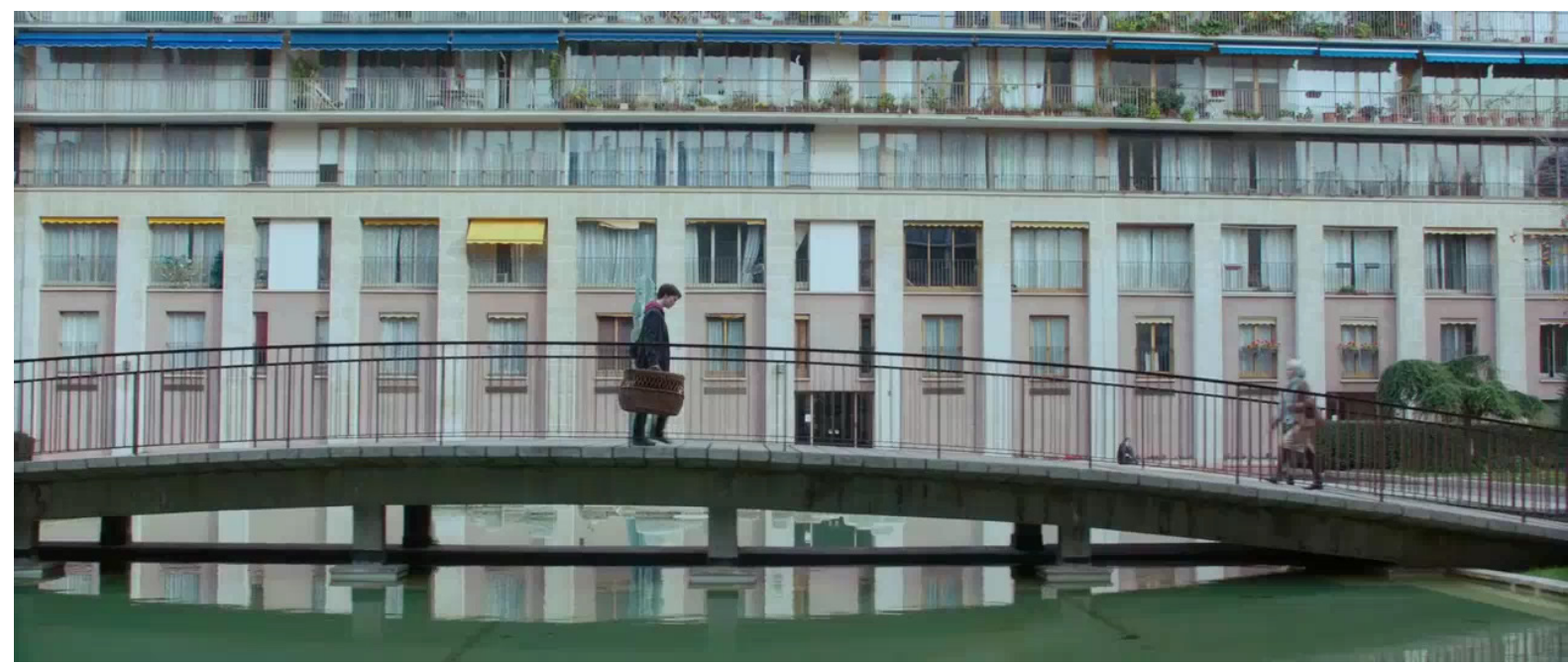

Görsel 7: Eşik Mekanı Olarak Köprü

İki nokta arasında bağ kuran bu eşik, geçmiş ile gelecek yeni ile eski, normal ile ötekini birbirinden ayırarak yeni bir yaşama ve heterotopyaya geçişe imkân tanımaktadır. Filmde Paul ile tanıştıktan sonra karın ağrıları ortadan kalkan Chloe, onunla aynı eve taşınmaya karar verir. Köprü ise filmde Chloe' nin Paul'un evine ulaşmak için kullanılan bir eşik mekânıdır. Geçmiş yaşamının hastalıklı durumunu ortadan kaldırmak için geçilen bu eşik, yeni bir yaşama doğru alınan yolu simgelemektedir. Böylece filmde kullanılan köprü, öteki ile normal olanı ayırmanın koşulu olarak ortaya çıkmaktadır.

\section{Sonuç}

Foucault'nun heterotopya kuraminı temel alarak L'Amant Double filminde yer alan heterotopik mekanları inceleyen bu çalışma, sapma heterotopyaları olarak psikiyatri kliniklerini, zaman heterotopyası olarak müzeleri, ayna heterotopyasını ve heterotopyalara geçiş mekanı olan eşikleri incelemiştir. Çalışma, Foucault'nun heterotopya kuramını temel alırken, bu heterotopyaların öteki mekân olmasına dikkat edilmiştir. İktidarın denetiminin dışında kalan heterotopya, modern insanın kendine aradığı ve yöneldiği bir kaçış mekânı olarak belirmektedir. Chloe karakterinin psikolojik çıkmazlarını konu alan bu film, karakterin yöneldiği farklı mekânsal alanlar ile heterotopya arasında bağ kurmayı kolaylaştırmaktadır. Film, psikoloji ve cinsellik çerçevesinde ilerlemesine karşın, filmde kullanılan mekan unsurları filmi heterotopya bağlamında öne çıkarmaktadır. Heterotopya kavramının öznenin psikolojik yapisıyla olan bağı, onun toplumda öteki olarak nitelendirilmesine ve kendine yeni bir mekân aramasına neden olmaktadır. Böylece film, Chloe'nin psikolojik durumuyla başa çıkma yollarını ararken mekan unsurlarını ve bu mekanlarda kullanılan nesneler ile bağ kurmamızı istemektedir.

Filmde ilk dikkat çeken heterotopya sapma heterotopyası olarak psikiyatri klinikleridir. Filmde yer alan her iki psikiyatri kliniği de Chloe'nin ruhsal dünyasına ilişkin kapıyı aralamaktadır. Sapkın davranışa sahip olanların yerleştirildikleri bu heterotopya, filmde Chloe'nin kendi isteğiyle yöneldiği mekânsal unsurlar olarak görülür. Zaman heterotopyası olarak müze, filmde kullanılan bir başka heterotopyadır. Müzelerin geçmişi biriktirme niteliği filmde yerini Chloe'nin zihinsel iz düşümlerine bırakır. Bu zihinsel tasavvurlar, müzede 
sergilenen nesneler üzerinden aktarılarak, Chloe'nin zihni gibi işlev görür. Yönetmenin izleyiciye sunduğu bu mekân, izleyicinin asla göremeyeceği Chloe'nin zihni halini alır.

Ayna heterotopyasına filmde sıkça yer veren yönetmen, karakterlerin ruhsal yapısını ayna üzerinden aktarmaktadır. Aynanın olmayan yer olarak heterotopya olması, aslında bir gölge gibi karakterleri olmayan bir yerde göstermektedir. Aynada karakter hem vardır hem de yoktur, hem orada olur hem de oraya gerçekte asla ulaşamaz. Filmde kullanılan heterotopik alanlarda dikkat çeken ayna, öznenin kendisini olmadığı yerde görmesine neden olarak bir yanılsama yaratır. Filmde adı geçen heterotopyalara ulaşmak için kullanılan mekân unsuru ise eşiklerdir. Eşikler olarak merdivenlere, kliniklerin bekleme odalarına ve köprülere yer veren film, geçiş mekânı olarak karakterin geçirdiği dönüşümünü anlamamıza olanak sağlamaktadır.

\section{Kaynakça}

Butler, J. (2015). İktidarın psişik yaşamı: Tabiyet üzerine teoriler. (Çev. Fatma Tütüncü). İstanbul: Ayrıntı Yayınları.

Canpolat, N. (2005). Foucault. Kadife karanlık: 21. Yüzyıl iletişim çağını aydınlatan kuramcılar içinde. (s.75-138). İstanbul: Su Yayınları.

Çoban, B. (2005). Lacan: Aynalar şövalyesi ya da bilinçdışının kaşifi. Kadife karanlık: 21. Yüzyıl iletişim çă̆ını aydınlatan kuramcılar. (s.277-294). İstanbul: Su Yayınları.

Éric Altmayer, E. Altmayer, N. (Yapımc1). \&Ozon F. (Yönetmen). (2017). L'Amant Double. [Sinema Filmi]. Fransa- Belçika: Mandarin Cinema.

Eroğlu, M. Güzin, K. Gürgen, O. Özerden, E. Doğanyılmaz, S., Özbay, N. (2010). Patolojik olarak tanı konulan paravajinal dermoid kist: nadir görülen bir olgu. Turkiye Klinikleri J Gynecol Obst 20(5):348-50.

Foucault, M. (2011). Özne ve iktidar. (Çev: Işık Ergüden- Osman Akınhay). İstanbul: Ayrıntı Yayınları.

Foucault, M. (2015). Cinselliğin tarihi. (Çev. Hülya Uğur Tanrı̈ver). İstanbul: Ayrıntı Yayınları.

Foucault, M. (2017). Hapishanenin doğuşu: Gözetim altında tutmak ve cezalandırmak. (Çev. Mehmet Ali Kılıçbay). Ankara: İmge Kitabevi.

Freud, S. (2012). Narsizm üzerine ve schreber vakası. (Çev.: Banu Büyükkal-Saffet Murat Tura). İstanbul: Metis Yayınları.

Geçtan, E. (2014). Psikanaliz ve sonrası. İstanbul: İmge Yayınları.

Harvey, D. (2012). Postmodernliğin durumu: kültürel değişimin kökenleri. (Çev.: Sungur Savran). İstanbul: Metis Yayınları.

Iwan Sudradjat ( 2012 ). Foucault, the Other Spaces, and Human Behaviour. Procedia - Social and Behavioral Sciences. $3628-34$.

Kovachev E, Ivanova V, Kisyov S. (2015). The "Vanishing Twin" syndrome - a myth or clinical reality in the obstetric practice? J of IMAB. Jul-Sep;21(3):853-855. DOI: http:/ /dx.doi. org/10.5272/jimab.2015213.853 Received: 18/05/2015; Published online: 04/09/2015

Lefebvre, H. (2014). Mekânın üretimi. (Çev. Işık Ergüden). İstanbul: Sel Yayıncılık.

Richter, R. (2013). Sosyolojik paradigmalar: klasik ve modern sosyoloji anlayışlarına giriş. (Çev.:

Necmettin Doğan).İstanbul: Küre Yayınları.

Sarup, M. (2017). Post-yapısalcılık ve postmodernizm. (Çev. Abdülbaki Güçlü). Ankara:

Pharmakon Yayınevi.

Stavrides, S. (2016). Kentsel heterotopya: özgürleşme mekânı olarak eşikler kentine doğru. (Çev.: Ali Karatay). İstanbul: Sel Yayıncılık. 
Stavrides S. (2018). Müşterek mekân: müşterekler olarak şehir. (Çev.: Cenk Saraçoğlu). İstanbul: Sel Yayıncilik.

Urry, J. (2015). Mekânları tüketmek. (Çev.: Rahmi G. Öğdül). İstanbul: Ayrıntı Yayınları.

Yılmaz, Z. Ş.(2018). Thomas bernhard'ın 'der kulterer' adlı yapıtında heterotopya. Ankara: Akçağ Yayınları.

Güngör, Ş. (E-Makale). Görsel kompozisyonun bir ögesi olarak çizgi (https:/ / dergipark.org.tr/ en/download/article-file/28665). Erişim Tarihi: 10.01.2020

\section{Internet Kaynakları}

https://thefunambulist.net/cinema/heterotopias-in-cinema-introduction

(Erişim Tarihi: 18.01.2020)

http://www.hermetics.org/rakam.html.

(Erişim Tarihi: 10.01.2020)

http:/ / blog.milliyet.com.tr/

(Erişim Tarihi: 1.10.2020)

https:/ /hiskind.com/in-conversation-with-lamant-double-director-francois-ozon

(Erişim Tarihi: 1.10.2020)

http://www.baskasinema.com/wp-content/uploads/2017/11/lamant-double-bulten-444. pdf

(Erişim Tarihi: 1.10.2020) 